\title{
Influence of physical damage and freezing on histamine concentration and microbiological quality of yellowfin tuna during processing \\ Gonzalo GARCÍA-TAPIA ${ }^{1}$, Guillermo BARBA-QUINTERO ${ }^{1,2}$, José Alberto GALLEGOS-INFANTE ${ }^{1}$ Ramón PACHECO AGUILAR ${ }^{3}$, Juan Antonio RUÍZ-CORTÉS², José Alberto RAMÍREZ ${ }^{4 *}$
}

\begin{abstract}
Yellowfin tuna has a high level of free histidine in their muscle, which can lead to histamine formation by microorganisms if temperature abuse occurs during handling and further processing. The objective of this study was to measure levels of histamine in damaged and undamaged thawed muscle to determine the effect of physical damage on the microbial count and histamine formation during the initial steps of canning processing and to isolate and identify the main histamine-forming microorganisms present in the flesh of yellowfin tuna. Total mesophilic and psicrophilic microorganisms were determined using the standard plate method. The presence of histamine-forming microorganisms was determined in a modified Niven's agar. Strains were further identified using the API 20E kit for enterobacteriaceae and Gram-negative bacilli. Physically damaged tuna did not show higher microbiological contamination than that of undamaged muscle tuna. The most active histamine-forming microorganism present in tuna flesh was Morganella morganii. Other decarboxylating microorganisms present were Enterobacter agglomerans and Enterobacter cloacae. Physical damage of tune during catching and handling did not increase the level of histamine or the amount of microorganisms present in tuna meat during frozen transportation, but they showed a higher risk of histamineforming microorganism growth during processing.
\end{abstract}

Keywords: yellowfin tuna; histamine; processing; freezing.

\section{Introduction}

Tuna species are important globally because of their high market demand and high price. The main attributes of these fish species include their flavor, nutritional value, and high lipid content. These fishes have a high proportion of eicosapentaenoic (EPA, 20:5n-3) and docosahexaenoic (DHA, 22:6n-3) acids, which are the longest $\mathrm{n}-3$ fatty acids in foods. (SALES, 2010; ROY et al., 2011). Although currently almost all tuna is wildcaught, tuna aquaculture technology continues to develop; one additional objective of this technology is to prevent the depletion of natural stocks by overfishing (ROY et al., 2010; MIYAKE et al., 2011). Despite the nutritive aspect, the consumption of tuna and other fishes belonging to the Scomberesocidae and Scombridae families has been associated with histamine poisoning, a foodborne illness. These fish species have in common a high level of histidine in their muscle (TSAI et al., 2004; OVISSIPOUR et al., 2011); histidine can be transformed into histamine by decarboxylating microorganisms if microbiological risks are not avoided during processing (BEN-GIGIREY et al., 1999; TSAI et al., 2004; BJORNSDOTTIR-BUTLER et al., 2010; FERNÁNDEZ-NO et al., 2010). Although refrigeration and frozen storage can extend the shelf life of seafood products, there are various psychotrophic bacteria growing in the freezing brine that contaminate tuna. Tuna also have psychotrophic bacteria growing in their gut, which can contaminate the flesh during the gutting process and can increase in numbers if temperature abuse occurs during processing. If decarboxylating microorganisms are present in the flesh, they can induce the formation of high levels of histamine in the final product, and the level of histamine formed is affected by the combination of both time and temperature. The most frequently occurring microorganisms associated with fish histamine poisoning are Enterobacteriaceae, Morganella morganii, Klebsiella pneumonia, and Hafnia (KIM et al., 2000). However, a variety of bacteria capable of producing histamine has been identified in fish (KIM et al., 2000; ECONOMOU et al., 2007; CHEN et al., 2008; BJORNSDOTTIR-BUTLER et al., 2010; FERNÁNDEZ$\mathrm{NO}$ et al., 2010). Some countries have established legal limits, or at least tolerable maximum contents for histamine in fish and fish products. The US Food and Drug Administration (FDA) has established a defect action level of $50 \mathrm{ppm}$ for histamine in tuna, mahi-mahi (dolphin), and other fish species as an indication of potential health risk (FOOD..., 1996). The European Community has fixed $100 \mathrm{ppm}$ for fish and fish products as a maximum average value in a group of 9 samples (VECIANANOGUES et al., 1995). Mexico has a maximum limit of $200 \mathrm{ppm}$ of histamine for tuna and tuna products.

Frequently, tuna shows physical damage in the flesh because of shipboard handling operations. Some of this damage is associated with crushing due to the great volume caught. In addition, tuna is sometimes damaged by operators during boat offloading (GILL; PENNEY, 1977; CRAVEN et al., 2001). These damaged fish may contain or induce higher histamine

\footnotetext{
Received 19/12/2012

Accepted 15/5/2013 (005968)

Departamento de Ingeniería Química y Bioquímica, Instituto Tecnológico de Durango - ITD, Mazatlán, Durango, México

2 Carretera Internacional Mazatlán, Instituto Tecnológico de Mazatlán - ITM, Mazatlán, Sinaloa, México

3 Centro de Investigación en Alimentación y Desarrollo, Asociación Civil, Hermosillo, Sonora, México

${ }^{4}$ Dirección General de Innovación Tecnológica, Centro Universitario, Ciudad Victoria, Universidad Autónoma de Tamaulipas - UAT, Tamaulipas 87143 México,

e-mail: ramirez@uat.edu.mx

${ }^{*}$ Corresponding author
}

DOI: http://dx.doi.org/10.1590/S0101-20612013005000061 
levels. Currently, there is a lack of sufficient information about both the formation of histamine in yellowfin tuna (Thunnus albacares) processed in Mexico and the microorganism involved in the formation of histamine during processing. Yellowfin tuna Canning is the second most economically important fishing industry activity in Mexico.

The objective of this study was to measure levels of histamine in damaged and undamaged thawed tuna muscle to determine the effect of physical damage on the microbial count and histamine formation during the initial steps of canning processing and to isolate and identify the main histamineforming microorganisms present in the flesh of yellowfin tuna.

\section{Materials and methods}

\subsection{Tuna}

Yellowfin tuna (Thunnus albacares) were caught by a Mexican commercial fishing boat in the Pacific Ocean, frozen on board by immersion in freezing brine, and stored at $-17^{\circ} \mathrm{C}$. Ten tuna measuring 12/20 were sampled directly from the boat immediately after their arrival by personnel working in the tuna canning industry quality control laboratory in Sinaloa, Mexico. In this study, only fish showing external physical damage on the upper loin of their body (gaps, perforations or cuts in their flesh) were selected.

\subsection{Sampling}

Using an electric saw previously sterilized with ethanol at $70 \%$, samples of almost one kilogram were cut from the upper loin of each fish; these samples were placed in sterile bags before ice-storing, transported to the laboratory in less than $10 \mathrm{~min}$, and stored at $-15^{\circ} \mathrm{C}$ until analysis (less than $24 \mathrm{~h}$ after the samples arrived at the laboratory). The samples were obtained from both a physically damaged region and an undamaged loin region of the same fish. The samples were stored at $-15^{\circ} \mathrm{C}$ until analysis.

\subsection{HPLC analysis of histamine}

The histamine-forming ability of isolated bacteria was determined using the HPLC technique previously described by Pacheco-Aguilar, Lugo-Sánchez and Robles-Burgueño (2000). Briefly, $25 \mathrm{~g}$ of fish flesh was homogenized with $100 \mathrm{~mL}$ 7.5\% TCA at $4{ }^{\circ} \mathrm{C}$ for $2 \mathrm{~min}$ in a Waring blender. The homogenate was centrifuged at $5,000 \times g$ for $15 \mathrm{~min}$ using a refrigerated centrifuge $\left(0\right.$ to $\left.4{ }^{\circ} \mathrm{C}\right)$. The supernatant was filtered through Whatman paper No. 1 , and the filtrate was stored at 0 to $4{ }^{\circ} \mathrm{C}$ until use. Histamine was derivatized using $10 \mathrm{mg}$ of OPA (o-phthaldialdehyde) dissolved in $250 \mu \mathrm{L}$ of methanol, $37.5 \mu \mathrm{L}$ of $30 \%$ Brij 35 solution, and $25 \mu \mathrm{L}$ of 2 -mercaptoethanol. This solution was diluted to $10 \mathrm{~mL}$ with $1 \mathrm{M}$ sodium borate buffer ( $\mathrm{pH} 10.4)$, mixed well, and stored under refrigeration in the dark for $24 \mathrm{~h}$ prior to use. Derivatization was performed immediately prior to loading the sample into the HPLC injection loop by mixing $0.25 \mathrm{~mL}$ of the OPA solution with a $0.25 \mathrm{~mL}$ aliquot of the extract. The solution was passed through a $0.2-\mu \mathrm{m}$ millipore filter and was injected 2 min after derivatization.
HPLC analyses were performed using a Varian high-pressure liquid chromatography equipment (Varian Assoc. Inc. Walnut Creek, Calif., U.S.A.) consisting of a Model 9102 pump, a Rheodyne Model 7125 injection valve with a $10 \mu \mathrm{L}$ capacity loop (Rheodyne Inc., Catati, Calif., U.S.A.), and a Varian fluorescence detector Model 9070. Fluorescence was monitored at $350 \mathrm{~nm}$ for excitation and $450 \mathrm{~nm}$ for emission wavelengths. A Beckman Ultrasphere ODS RP 18 reverse-phase column $(5 \mu \mathrm{m}$, $250 \mathrm{~mm} \times 4.6 \mathrm{~mm}$ i.d.) (Beckman Instruments, Inc., Fullerton, Calif., U.S.A.) was used for the separation. The mobile gradient phase consisted of methanol and $0.1 \mathrm{M}$ sodium acetate buffer $\mathrm{pH} 6.2[(1 \mathrm{~L}+10 \mathrm{~mL}$ tetrahydrofuran $(\mathrm{THF})]$. Flow rate was set at $1.2 \mathrm{~mL} / \mathrm{min}$. Chromatogram recordings and integrations were calculated using Varian 3.4 software (Varian Assoc. Inc. Walnut Creek, Calif., U.S.A.). Quantification was done using a- aminobutyric acid $(0.05 \mu \mathrm{mol} / \mathrm{mL})$ as an internal standard.

\subsection{Total viable count}

Microbiological analysis was determined by blending $10 \mathrm{~g}$ of muscle with $90 \mathrm{~mL}$ peptone water $(0.1 \%)$. An agar plate count was carried out in duplicate in accordance with the standard plate method. One-milliliter aliquots from each sample were serially diluted with peptone water $(0.1 \%)$ and mixed with standard plate count agar that had been supplemented with $0.5 \%$ $\mathrm{NaCl}$ at $50^{\circ} \mathrm{C}$. Total counts of psychrophilic microorganisms were obtained incubating at $5{ }^{\circ} \mathrm{C}$ for 10 days, and total counts of mesophilic microorganisms were obtained incubating at $37^{\circ} \mathrm{C}$ for $48 \mathrm{~h}$.

\subsection{Histamine-forming microorganisms}

A histaminic-forming population was determined using the technique described by Niven Junior, Jeffrey and Corlett Junior (1981). Ten grams of muscle were homogenized as previously described for total viable count, and $1 \mathrm{~mL}$ of suitable dilutions was inoculated in modified Niven's agar containing $0.5 \%$ triptone, $0.5 \%$ yeast extract, $2.0 \% \mathrm{~L}$-histidine $2 \mathrm{HCl}, 0.5 \% \mathrm{NaCl}$, $0.1 \%$ Calcium carbonate, $3.0 \%$ bacteriologic agar (Bioxon), and $0.006 \%$ bromocresol purple; $\mathrm{pH}$ was adjusted to 5.5 with $0.1 \mathrm{~N} \mathrm{HCl}$. Petri dishes were incubated at $5{ }^{\circ} \mathrm{C}$ for ten days to determine the presence of psychrophilic microorganisms, and the presence of mesophilic microorganisms were determined by incubating at $37^{\circ} \mathrm{C}$ for $48 \mathrm{~h}$. Colonies showing a purple halo were considered to be histamine-forming bacteria.

\subsection{Isolation and identification of histamine-forming bacteria}

Colonies showing a purple halo with different morphological characteristics (form, elevation, color and halo intensity) were selected and inoculated into modified TSAH (tryptose-soycasein agar) medium supplemented with $0.1 \%$ of L-histidine at pH 7.0, in accordance with López-Sabater et al. (1996a) and Du et al. (2002).

Strains were further identified by the use of the API 20E kit for enterobacteriaceae and Gram-negative bacilli (Biomerieux, Marcy L'Etoile, France) and biochemical tests (Gram-negative, 
catalase production, oxidase activity, motility, nitrate reduction, and nitrogen production).

\subsection{Histamine production}

The capability of producing histamine was determined by inoculating isolated histamine-forming microorganisms in a medium containing $400 \mathrm{~g} / \mathrm{L}$ of tuna flesh, $10 \mathrm{~g} / \mathrm{L}$ of peptone and $25 \mathrm{~g} / \mathrm{L}$ of histidine. The medium was sterilized before inoculation at $121^{\circ} \mathrm{C}$ for $15 \mathrm{~min}$ (NIVEN JUNIOR; JEFFREY; CORLETT JUNIOR, 1982).

\subsection{Statistical analysis}

Statistical analysis was performed using Statgraphics 5.0 (Software Publishing Corporation, Bitstream Inc.). LSD's multiple range tests were used to determine significant differences $(\mathrm{P}<0.05)$ among the treatments.

\section{Results and discussion}

\subsection{Microbiological analysis}

The influence of physical damage in the content of total viable count and histamine-forming microorganisms in the flesh of thawed tuna just before processing was determined. These results are shown in Table 1.

The damaged flesh showed a higher level of mesophilic microorganisms $\left(1.7 \times 10^{5} \mathrm{CFU} / \mathrm{g}\right)$ than that of the undamaged flesh $\left(9 \times 10^{4} \mathrm{CFU} / \mathrm{g}\right)$; however, this difference was not significant $(\mathrm{P} \leq 0.05)$. Guillén-Velasco et al. (2004) found that bluefin tuna skin showed a higher total viable count than that of the muscle. The origin of the external contamination of tuna is associated with the contamination of the seawater, freezing brine, handling operations, and fresh water used for thawing tuna (GILL; PENNEY, 1977; CRAVEN et al., 2001; LORCA et al., 2001).

Damaged and undamaged tuna flesh samples showed high levels of mesophilic histamine-forming bacteria $\left(5 \times 10^{3}\right.$ and $5.3 \times 10^{3}$ ) $($ Table 1$)$. Psychrophilic histamine-forming microorganisms were not detected in any sample. Histamineforming bacteria are mesophilic microorganisms whose histamine-forming ability is affected by storage temperature. These microorganisms have been reported to reach minimal activity at temperatures lower than $4{ }^{\circ} \mathrm{C}$, with no activity at $0{ }^{\circ} \mathrm{C}$ (LÓPEZ-SABATER et al., 1996b, SILVA; DA PONTE; ENES-

Table 1. Microbiological count and histamine level in tuna muscle.

\begin{tabular}{lcc}
\hline \multicolumn{1}{c}{ Parameter } & Undamaged flesh & Damaged flesh \\
\hline Mesophilic aerobic (CFU/g) & $9 \times 10^{4 \mathrm{a}}$ & $1.7 \times 10^{5 \mathrm{a}}$ \\
& $\left(4.9 \times 10^{4}\right)$ & $\left(9.7 \times 10^{4}\right)$ \\
Mesophilic histamine-forming & $5 \times 10^{3 \mathrm{a}}$ & $5.3 \times 10^{3 \mathrm{a}}$ \\
bacteria (CFU/g) & $\left(2.3 \times 10^{3}\right)$ & $\left(2.5 \times 10^{3}\right)$ \\
$\begin{array}{l}\text { Psychrophilic histamine-forming } \\
\text { bacteria (CFU/g) }\end{array}$ & 0 & 0 \\
Histamine level $(\mathrm{ppm})$ & $40(8.8)^{\mathrm{a}}$ & $49(9.6)^{\mathrm{a}}$ \\
\hline
\end{tabular}

a,bletters indicate significant differences between treatments $(P \leq 0.05)$. Mean values of analysis of 9 tuna samples in duplicate. Values in parentheses show the standard deviation.
DAPKEVICIUS, 1998; KIM; AN; PRICE, 1999; DU et al., 2002; BERMEJO et al., 2003). The histidine decarboxylase enzyme is fully inactivated at temperatures below $-8{ }^{\circ} \mathrm{C}$ (BURNS, 1985).

The flesh of damaged tuna showed similar total viable count but equal histamine-forming bacteria levels when compared with undamaged tuna. Aside from these findings, there was no significant difference $(\mathrm{P}<0.05)$ in the concentration of histamine between the damaged (36-53 ppm) and undamaged tuna muscle (34-59 ppm) (Table 1). These results indicated that physically damaged muscle was not more susceptible to microbiological contamination during frozen transportation, thus indicating that at low temperature there is a minimal formation of histamine. Three of the tuna fish samples showed levels of histamine higher than the upper limit established for the FDA (50 mg-kg) (FOOD..., 1996).

\subsection{Identification of histamine-forming bacteria}

Colonies of microorganisms with different morphological aspects forming a purple halo in Niven's medium were selected and identified with the API 20E kit system used to detect enterobacteriaceae and Gram-negative bacilli. Niven Junior, Jeffrey and Corlett Junior (1981) found that histamine-forming microorganisms isolated in his study were mesophilic bacteria from the Enterobacteriaceae family, and according to MacFaddin (1990), Enterobacteriaceae bacteria are Gram-negative, catalase-positive, and oxidase-negative. Further biochemical tests indicated that all isolated strains were Gram-negative, catalase-positive, oxidase-negative, and showed no motility. A total of twelve different colonies were analyzed, and the results obtained are shown in Table 2. Identified colonies included three Enterobacter agglomerans, two Enterobacter cloacae, three Morganella morganii colonies, and four other unidentified colonies.

Morganella morganii has been reported as a short bacilli Gram-negative, catalase-positive, and oxidase-negative (KIM et al., 2001) bacterium frequently found in tuna and tuna products, including yellowfin tuna, associated with the presence of histamine. Morganella morganii is considered one of the most efficient histamine-forming bacteria and has been associated with several histamine outbreaks resulting from tuna consumption (BJORNSDOTTIR-BUTLER et al., 2010, 2011; FERNÁNDEZ-NO et al., 2010).

Enterobacter cloacae has been frequently reported as a histamine-forming bacterium present in different tuna species, including yellowfin and bluefin tuna. Enterobacter agglomerans has rarely been reported as a histamine-forming bacterium associated with tuna, but it has been found in yellowfin tuna (DU et al., 2002), bluefin tuna (LÓPEZ-SABATER et al., 1994), and commercial tuna products (TAYLOR et al., 1979).

\subsection{Histamine-production ability}

The histamine-production ability of the three identified bacteria was determined by inoculating each of them in a medium containing $25 \mathrm{~g} / \mathrm{L}$ of histidine (tuna flesh, water, histidine, and peptone) and by incubating them at $37 \pm 2{ }^{\circ} \mathrm{C}$ for 24 hours. The changes in concentration of histidine and 
Table 2. Microorganisms identified using the API 20E kit and biochemical tests.

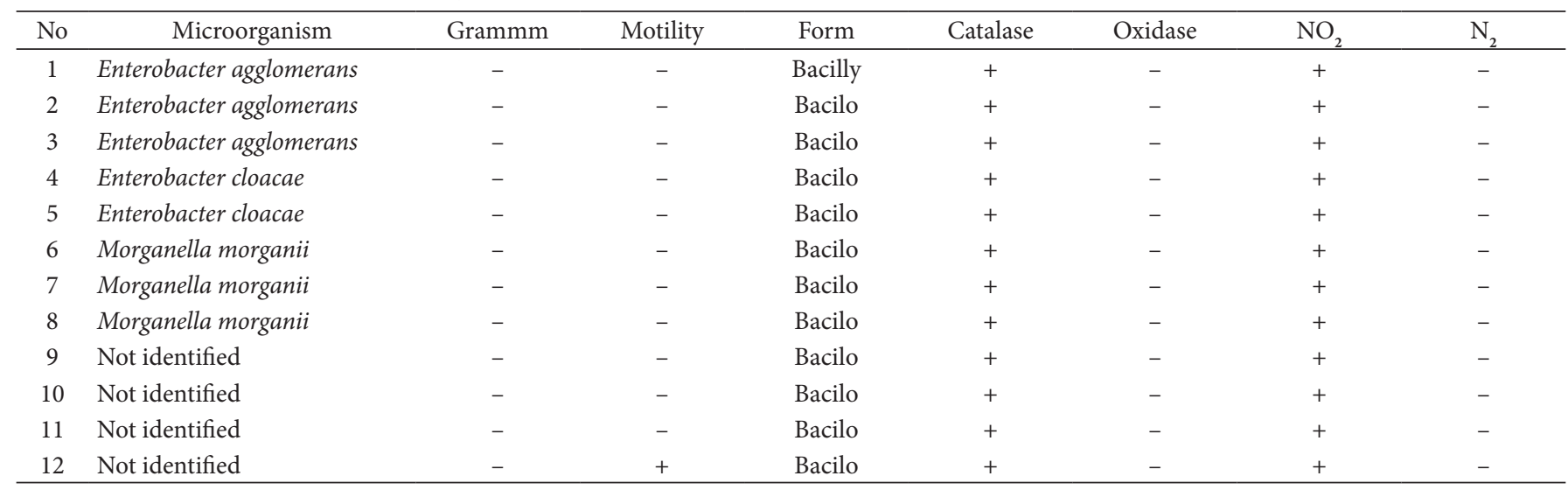

Table 3. Histamine-production ability of strains isolated from yellowfin tuna.

\begin{tabular}{cc}
\hline $\begin{array}{c}\text { Presumptive } \\
\text { strain }\end{array}$ & $\begin{array}{c}\text { Histamine production } \\
(\mathrm{ppm} \text { in } 24 \mathrm{~h})\end{array}$ \\
\hline Enterobacter agglomerans & 446.90 \\
Enterobacter agglomerans & 420.38 \\
Enterobacter agglomerans & 435.12 \\
Enterobacter cloacae & 499.35 \\
Enterobacter cloacae & 418.20 \\
Morganella morganii & 5802.91 \\
Morganella morganii & 6034.89 \\
Morganella morganii & 6245.42 \\
\hline
\end{tabular}

the increased histamine in the medium were determined using HPLC. Results are shown in Table 3. Although all the microorganisms studied produced histamine, their ability to transform histidine into histamine varied. All three species produced a high level of histamine during the first 24 hours. Enterobacter agglomerans and Enterobacter cloacae were less efficient than Morganella morganii in transforming histidine into histamine under the conditions used in this study (Table 3). Enterobacter agglomerans transformed only 5.1 to $5.8 \%$ of the histidine contained in the medium (10,000 ppm) into histamine, and Enterobacter cloacae transformed 4.4 to $5.2 \%$. Morganella morganii transformed 61.5 to $73.7 \%$ of the histidine into histamine. The higher ability of some microorganisms to convert histidine into histamine depends strongly on their enzymatic activity and their ability to grow in different environmental systems (EDMUNDS; EITENMILLER, 1975; KIM et al., 2002).

Morganella morganii has been reported as the most efficient decarboxylating microorganism in different studies (LÓPEZSABATER et al., 1994; LORCA et al., 2001; KIM et al., 2001, 2002; RODRÍGUEZ-JEREZ et al., 1994: DU et al., 2002)

\section{Conclusion}

The flesh from physically damaged tuna showed higher total viable counts but an equal number of mesophilic histamineforming bacteria than the flesh of undamaged tuna, indicating that the inappropriate handling of tuna during the processes of catching, freezing, transporting, and discharging greatly influences microbiological contamination. The histamine level of just-thawed tuna was lower than $50 \mathrm{ppm}$, and there was no presence of psychrophilic histamine-forming bacteria in any of the tuna samples investigated, and there was no difference in histamine level between damaged and undamaged muscles right after thawing. Therefore, histamine levels higher than $50 \mathrm{ppm}$ in final products can be associated with temperature abuse conditions during processing. Morganella morganii was the most active histamine-forming bacterium found in yellowfin tuna.

\section{Acknowledgments}

The authors are grateful to Fondo Mixto CONACYT Gobierno del Estado de Tamaulipas (Mexico) for the financial support. Publication of this article was funded by PIFI 20112012.

\section{References}

BEN-GIGIREY, B. et al. Histamine and cadaverine production by bacteria isolated from fresh and frozen albacore (Thunnus alalunga). Journal of Food Protection, v. 62, n. 8, p. 933-939, 1999. PMid:10456749.

BERMEJO, A. et al. Growth and characterization of the histamineforming bacteria of jack mackerel (Trachurus symmetricus). Journal of Food Process and Preservation, v. 26, p. 401-414, 2003.

BJORNSDOTTIR-BUTLER, K. et al. Development of a real-time PCR assay with an internal amplification control for detection of Gramnegative histamine-producing bacteria in fish. Food Microbiology, v. 28, p. 356-363, 2011. PMid:21356438. http://dx.doi.org/10.1016/j. fm.2010.06.013

BJORNSDOTTIR-BUTLER, K. et al. Development of molecular-based methods for determination of high histamine producing bacteria in fish. International Journal of Food Microbiology, v. 139, p. 161-167, 2010. PMid:20392504. http://dx.doi.org/10.1016/j. ijfoodmicro.2010.03.017

BURNS, F. D. Tuna handling and refrigeration on purse seiners. U.S. Department of Commerce, National Oceanic and Atmospheric Administration, National Marine Fisheries Service Technical Bulletin NOAA-TM-NMFS-SWR-011, 1985. 
CHEN, H. C. et al. Determination of histamine and histamineforming bacteria in tuna dumpling implicated in a food-borne poisoning. Food Chemistry, v. 106, p. 612-618, 2008. http://dx.doi. org/10.1016/j.foodchem.2007.06.020

CRAVEN, C. et al. Understanding and controlling histamine formation in troll-caught albacore tuna: A review of preliminary findings from the 1994 season. Corvallis, 2001. Oregon Sea Grant (ORESU-T-95-00).

DU, W. X. et al. Development of biogenic amines in yellowfin tuna (Thunnus albacares): Effect of storage and correlation with decarboxylase-positive bacterial flora. Journal of Food Science, v. 67, p. 292-301, 2002. http://dx.doi.org/10.1111/j.1365-2621.2002. tb11400.x

ECONOMOU, V. et al. Changes in histamine and microbiological analyses in fresh and frozen tuna muscle during temperature abuse. Food Additives and Contaminants, v. 24, p. 820-832, 2007. PMid:17613069. http://dx.doi.org/10.1080/02652030701278321

EDMUNDS, W. J.; EITENMILLER, R. R. Effect of storage time and temperature on histamine content and histidine decarboxylase activity of aquatic species. Journal of Food Science, v. 40, p. 515519, 1975. http://dx.doi.org/10.1111/j.1365-2621.1975.tb12518.x

FERNÁNDEZ-NO, I. C. et al. Differential characterization of biogenic amine-producing bacteria involved in food poisoning using MALDI-TOF mass fingerprinting. Electrophoresis, v. 31, p. 11161127, 2010. PMid:20151397.

FOOD AND DRUG ADMINISTRATION - FDA. Fish \& fisheries products hazards \& controls guide: first edition. Washington: FDA, Center for Food Safety and Applied Nutrition, Office of Seafood, 1996.

GILL, C. O.; PENNEY, N. Penetration of bacteria into meat. Applied and Environmental Microbiology, v. 33, p. 1284-1286, 1977. PMid:406846 PMCid:PMC170872.

GUILLÉN-VELASCO, S. et al. Histamine production by two enterobacteriaceae strains isolated from tuna (Thunnus thynnus) and jack mackerel (Trachurus murphyii). International Journal of Food Properties, v. 7, p. 91-103, 2004. http://dx.doi.org/10.1081/ JFP-120022984

KIM, S. H.; AN, H.; PRICE, R. J. Histamine formation and bacterial spoilage of albacore harvested off the U.S Northwest Coast. Journal of Food Science, v. 64, p. 340-343, 1999. http://dx.doi. org/10.1111/j.1365-2621.1999.tb15896.x

KIM, S. H. et al. Histamine and biogenic amine production by Morganella morganni isolated from temperature-abused albacore. Journal of Food Protection, v. 63, p. 244-251, 2000. PMid:10678431.

KIM, S. H. et al. Identification of bacterial crucial to histamine accumulation in Pacific mackerel during storage. Journal of Food Protection, v. 64, p. 1556-1564, 2001. PMid:11601705.

$\mathrm{KIM}, \mathrm{S}$. H. et al. Occurrence of histamine-forming bacteria in albacore and histamine accumulation in muscle at ambient temperature, Journal of Food Science, v. 67, p. 1515-520, 2002. http://dx.doi. org/10.1111/j.1365-2621.2002.tb10315.x

LÓPEZ-SABATER, E. I. et al. Bacteriological quality of tuna fish (Thunnus Thynnus) destined for canning: Effect of tuna handling on presence of histidine decarboxylase bacteria and histamine level. Journal of Food Protection, v. 57, p. 318-323, 1994.

LÓPEZ-SABATER, E. I. et al. Sensory quality and histamine formation during controlled decomposition of tuna (Thunnus thynnus). Journal of Food Protection, v. 59, p. 167-174, 1996a.
LÓPEZ-SABATER, E. I. et al. Incidence of histamine-forming bacteria in histamine content in scombroid fish species from retail markets in the Barcelona area. International Journal of Food Microbiology, v. 28 , p. 411-418, 1996b. http://dx.doi.org/10.1016/01681605(94)00007-7

LORCA, T. A. et al. Growth and histamine formation of Morganella morganii in determining the safety and quality of inoculated and uninoculated bluefish (Pomatomus saltatrix). Journal of Food Protection, v. 64, p. 2015-2019. 2001. PMid:11770632.

MacFADDIN, J. F. Biochemical test for identification of medical bacteria. Baltimore: The Williams and Wilkins Company, 1990. p. 255.

MIYAKE, Y. et al. Effects of brief summer or winter fasting on the muscle quality of cultured pacific bluefin tuna (Thunnus orientalis). Jounal of Aquatic and Food Product Technology, v. 20, p. 196208, 2011. http://dx.doi.org/10.1080/10498850.2011.558668

NIVEN JUNIOR, C. F.; JEFFREY, M. B.; CORLETT JUNIOR, D. A. Differential plating medium for quantitative detection of histamine producing bacteria. Applied and Environmental Microbiology, v. 41 , p. 321-322, 1981.

OVISSIPOUR, M. et al. Optimization of protein recovery during hydrolysis of yellowfin tuna (Thunnus albacares) visceral proteins. Journal of Aquatic and Food Product Technology, v. 20, p. 148159, 2011. http://dx.doi.org/10.1080/10498850.2010.548910

PACHECO-AGUILAR, R.; LUGO-SÁNCHEZ, M. E.; ROBLESBURGUEÑO, M. R. Postmortem biochemical and functional characteristic of Monterey sardine muscle stored at $0{ }^{\circ} \mathrm{C}$. Journal of Food Science, v. 65, p. 40-47, 2000. http://dx.doi. org/10.1111/j.1365-2621.2000.tb15953.x

RODRÍGUEZ-JEREZ, J. J. et al. Histamine, cadaverine and putrescine forming bacteria from ripened Spanish semi preserved anchovies. Journal of Food Science, v. 59, p. 998-1001, 1994. http://dx.doi. org/10.1111/j.1365-2621.1994.tb08176.x

ROY, B. C. et al. Proximate and fatty acid compositions in different flesh cuts of cultured, cultured fasted, and wild pacific bluefin tuna (Thunnus orientalis). Journal of Aquatic Food Product Technology, v. 19, p. 284-297, 2010. http://dx.doi.org/10.1080/10 498850.2010 .518281

SALES, J. Quantification of the differences in flesh fatty acid components between farmed and wild fish. Journal of Aquatic and Food Product Technology, v. 19, p. 298-309, 2010. http://dx.doi.or g/10.1080/10498850.2010.519861

SILVA, C. C. G.; DA PONTE, D. J. B.; ENES-DAPKEVICIUS, M. L. N. Storage temperature effect on histamine formation in big eye tuna and skipjack. Journal of Food Science, v. 63, p. 644-647, 1998. http://dx.doi.org/10.1111/j.1365-2621.1998.tb15803.x

TAYLOR, S. L. et al. Histamine production by Klebsiella pneumoniae and an incident of scombroid fish poisoning. Applied and Environmental Microbiology, v. 37, p. 274-278, 1979. PMid:373626 PMCid:PMC243199.

TSAI, Y. H. et al. Histamine-related hygienic qualities and bacteria found in popular commercial scombroid fish fillets in Taiwan. Journal of Food Protection, v. 67, p. 407-412, 2004. PMid:14968980.

VECIANA-NOGUES, M. T. et al. Liquid chromatographic method for determination of biogenic amines in fish and fish products. Journal of AOAC International, v. 78, p. 1045-50, 1995. PMid:7580316. 